\title{
THE ROLE OF LANGUAGE IN EUROPEAN NATIONALIST IDEOLOGIES ${ }^{1}$
}

\author{
Jan Blommaert \& Jef Verschueren
}

\section{Introduction}

In his book on Nations and nationalism since 1780, E.J. Hobsbawm concludes that "the phenomenon [of nationalism] is past its peak." (p. 183) Before he gets to this conclusion (apparently written some time in 1989, still before German reunification became a realistic possibility and before the process of fragmentation in some countries of the old Communist Bloc had gained momentum) he shows quite convincingly, and almost prophetically, that a new 'Europe of nations' in the Wilsonian sense (with independent entities such as Catalonia, Corsica, Slovenia, Estonia, etc.) could not produce 'a stable or lasting political system.' (p. 177) For one thing, "the first thing most such hypothetical new European states would do is, almost certainly, apply for admission to the European Economic Community, which would once again limit their sovereign rights, [...]." (p. 177)

Indeed, nation-states with highly autonomous 'national economies' probably belong to the past. However, it is far from clear that such a confrontation with economic reality, which will no doubt change the historical content and direction of nation-building processes, has any direct influence on nationalism from an ideological perspective. After all, as Hobsbawm demonstrates equally convincingly, the essence of nationalism from the 19th century onwards has been the definition of 'imagined communities' along conceptual lines out of touch with 'objective reality' (a theme also developed in Barth ed. 1982 and by Anderson 1983).

An assessment of the ideological processes involved requires access to 'the view from below.' But,

\begin{abstract}
"That view from below, i.e. the nation as seen not by governments and the spokesmen and activists of nationalist (or non-nationalist) movements, but by the ordinary persons who are the objects of their action and propaganda, is exceedingly difficult to discover." (Hobsbawm 1990, p. 11)
\end{abstract}

This is further complicated by the fact that

\footnotetext{
${ }^{1}$ This paper was written in the context of a research program supported by the Belgian National Fund for Scientific Research (NFWO/FKFO), the Belgian National Lottery and a Belgian government grant (IUAP-II, contract number 27). Thanks are due to Gino Eelen, who collected the data we needed, to Louis Goossens, Johan van der Auwera, Michael Meeuwis, Luisa Martín Rojo, Bambi Schieffelin, Kit Woolard and Paul Kroskrity for comments on an earlier version, and to Susan Philips for the insightful remarks she made during the discussion at the AAA meeting where this paper was presented.
} 
"[...] national identification and what it is believed to imply, can change and shift in time, even in the course of quite short periods." (Hobsbawm 1990, p. 11)

Hobsbawm adds that "this is the area of national studies in which thinking and research are most urgently needed today." (p.11) To counterbalance the remark about the 'exceeding difficulty' of the research in question, he observes:

"Fortunately social historians have learned how to investigate the history of ideas, opinions and feelings at the sub-literary level, so that we are today less likely to confuse, as historians once habitually did, editorials in select newspapers with public opinion." (p. 11)

This paper is intended to contribute (i) to the further exploration of the topic identified in the above quotations, and (ii) to the development of an adequate methodology to approach the complexities of ideology research.

As to its topic, this paper is to be situated in the context of a wider research project intended to provide a historical snapshot of mainstream European thinking about nations and national identification. The main data base consists of a comprehensive collection of articles on ethnic conflicts (whether intra- or internationally), separatist and unificational movements, and other topics -- such as minority politics -- involving issues of group identity associated with 'nationality,' from the mainstream daily press in at least $80 \%$ of the countries of Europe (both East and West), over a three-month period in 1991. Though the period itself may not be long enough for observable ideological changes to take place, the temporal demarcation will make it possible to draw historical comparisons with welldocumented periods from the past; moreover, similar snapshots can be taken at any time in the future.

From a methodological point of view, the nature of the data base might raise some worries directly related to Hobsbawm's remark concerning the earlier habits of historians 'to confuse editorials in select newspapers with public opinion.' There are three ways in which the project avoids this problem.

First, the selection criterion for choosing the newspapers to be investigated has been that they should be mainstream publications which, together, have a maximal readership, but each of which has a different target audience. Smallcirculation publications have been avoided because they are most likely to represent the opinions of a few people. ${ }^{2}$ In practice, extremist texts (in any direction) have, as a result, rarely entered the corpus, though -- depending on one's perspective -extremism of some kind may turn out to be the norm under certain circumstances and in some geographical areas.

Second, the investigation pays equal attention to regular news reports and editorials (which are more openly subject to personal interpretation and bias); the character of the texts is fully taken into account whenever conclusions are drawn from examples.

2 This statement can be correct only for a free-press tradition in which a wide range of publications is available. By now this is the case in most of Europe, though in the countries of the old communist bloc the situation is less stable than in the rest of Europe, and hence future repetitions of the same research design may reveal more rapid historical change there. 
Third, and most importantly, more weight is attached to the implicit frame of reference, the supposedly common world of beliefs in which the reports (or the editorial comments) are anchored, than to the explicit statements made by the reporters (or commentators). This approach is crucial for the investigation of widely shared ideologies. And fortunately modern linguistics, in particular linguistic pragmatics, provides us with fully adequate tools to undertake exactly this kind of study. Briefly, the basic assumptions are (i) that the authors, just like any other language user in any other communicative context, are unable to express what they want to communicate in a fully explicit way, (ii) that therefore their texts leave implicit most of the assumptions they expect their readers to share with them, and (iii) that a careful analysis of those implicit assumptions will reveal a common frame of reference or 'ideology.' It follows that isolated examples are never sufficient as evidence: coherence -- manifested either as recurrence or as systematic absence -is necessary to warrant conclusions. ${ }^{3}$

This article is based on a smaller pilot study in which some Northwest European data ${ }^{4}$ were scrutinized in view of the specific role which language plays in the overall picture of current nationalist ideologies. It goes without saying that our findings will have to be interpreted in the light of the regional restrictions on the corpus, a remark which should be kept in mind whenever we use the qualification 'European'.

\section{Language as a distinctive feature}

\section{The significance of a non-issue}

As a surface topic, worthy of an explicit treatment in its own right, language is strikingly absent in our corpus of reports on interethnic conflicts or on issues of 'national' identity or nation-building. But far from undermining any attempt to reveal a specific role for language in current nationalist ideologies from the start, this first observation has turned out to touch the very essence of popular linguistic ideology.

Language is raised to the level of an individual issue almost exclusively when reference is made to societies other than the one in which the report in question is itself to be situated. A case in point is a German report entitled Amerika und Einwanderung: Schmelztiegel oder Salatschüssel? [America and immigration: Melting

${ }^{3}$ A more elaborate justification of this approach is to be found in $\mathrm{J}$. Blommaert \& $\mathrm{J}$. Verschueren (1991).

${ }^{4}$ Most of the data used for this specific study date back to the first weeks of November 1990 , but they are not strictly confined to that period. The investigated publications are: Die Zeit, Zeit Magazin, Der Spiegel, Frankfurter Allgemeine, Frankfurter Allgemeine Magazin; The Guardian, The Guardian Weekly; NRC Handelsblad; Le Monde, Le Nouvel Observateur; De Standaard. For the sake of comparison, one non-European source (though clearly 'Western' if not specifically American, and widely read in Europe), The International Herald Tribune, was studied for the same period. As will be clear from the examples, the general tendency turned out to be very similar. 
pot or salad bowl?], juxtaposed to an article on a dispute over voting rights at the municipal level for minority members in Germany. Though the physical juxtaposition of the two articles is clearly based on a judgment of topical relatedness, the German issue is phrased exclusively in terms of the sharing of political power and the possible infringement of ethnic German rights, whereas language is explicitly focused on as an issue in the US:

"Heute schon spielen sich harte Kämpfe um die Sprache, um die Dominanz des Englischen ab, das vorläufig noch eine verbindende Kraft darstellt." (Die Zeit, 9 Nov. 1990, p. 7) [Already today difficult battles are fought over language, the dominance of English, which -- for the time being -- still presents a unifying force.]

The Official English movement is indeed a sufficiently interesting phenomenon to deserve special mention in connection with the multiethnicity of the United States. ${ }^{5}$ But implicit in this German report is the idea that the coherence of a society strongly benefits from the existence of just one language. It is not accidental that the quoted sentence follows an explicit statement to the effect that

"Die ethnisch-rassische Koexistenz scheint zu gelingen solange die Wirtschaft einigermassen floriert." [Ethnic-racial coexistence seems to work as long as the economy is somewhat successful.]

Linguistic strife is presented as an important force towards social disintegration, triggered by a worsening economy. Because of the need for linguistic coherence, German as the only language of Germany is taken for granted. The issue, which is in reality as acute as in the American case (though there is not one single 'threatening' alternative such as Spanish in the US), does not need to be mentioned. Thus, treating language as a non-issue in relation to German minority problems, only reveals how much is really taken for granted.

\section{Language: $A$ marker of identity}

That language is seen as a unifying force should be clear from the above. Language assumes the character of a clear identity marker. Thus it appears prominently in an article on Spanish Basque nationalism (entitled Der Heimat bewusst: Die Basken -gastfreundlich aber nicht servil [Conscious of the 'Heimat': The Basques: hospitable but not humble]):

"Was steckt dahinter? Eine lange Geschichte der allerdings militanten
Selbtstbehauptung eines Volkes, dessen Herkunft ebenso wie die Herkunft
seiner Sprache, des Euskara, den Ethnologen und Linguisten bis heute
Rätsel aufgibt. [...] Diese Ursprache [...]." (Die Zeit, 16 Nov. 1990, p. 83)
[What's behind it? <i.e. behind Basque nationalism> A long history of clearly militant
selfpreservation of a people, of which the origin, as well as the origin of its language,

\footnotetext{
${ }^{5}$ For further discussions of this particular movement which strongly relates national identity to language, see Adams \& Brink (eds.) (1990).
} 
Euskara, has until today been a mystery for ethnologists and linguists. $<\ldots>$ This ancient language $<\ldots>$.]

The language of the Basques, of which not enough may be known to designate it as 'Ursprache' (if such a designation has any meaning at all), becomes the romantic focus of the identity of the Basque people in a description which is reminiscent of nineteenth-century scholarship.

\section{Natural discontinuities}

Yet, language is only one identity marker among others. Descent, history, culture, religion, and language are treated as a feature cluster. Their identificational function implies separability, a natural discontinuity in the real world. These discontinuities are 'nations' or 'peoples,' i.e. natural groups, the folk perceptions of which conceptualizes them in much the same way as species in the animal kingdom. If feathers are predictive of beaks, eggs, and an ability to fly, so is a specific language predictive of a distinct history and culture. ${ }^{6}$

Thus the absence of the feature 'distinct language' tends to cast doubts on the legitimacy of claims to nationhood. Consider the following statements from an article on the Ukraine, made in the context of references to the 'russification' of the republic:

"The poor old Ukraine has had a bad press. Both the Poles, who dominated the towns of the western part, and the Russians, who dominated those of the east and south, looked down on the Ukrainians as peasants, speaking jargon. The language itself varied greatly from region to region -- in the west quite close to Polish, in the east sometimes indistinguishable from Russian. [...] Politically. the Ukraine was underdeveloped [...]." (The Guardian Weekly, 4 Nov. 1990, p.9)

Here the lack of a clearly distinct language is the first item in a list of indicators of cultural erosion or underdevelopment.

In some cases, language is offered as the only distinctive trait of a 'group'; others are not really needed, since a distinctive language is predictive of a distinct group identity. This strategy is typically used when little-known ethnic groups are talked about. A case in point is the reporting on the Gagauz people in Moldavia:

"[...] the defiant Turkish-speaking Gagauz districts [of Moldavia]" (Guardian Weekly, 4 Nov. 1990, p. 6)

\footnotetext{
${ }^{6}$ Exactly the same ideological phenomenon is observed by Uli Windisch $(1990)$ in his study of Swiss nationalism and xenophobia. He calls it 'essentialism' and describes it as follows: "Every system of political and social representation is organised around essences, natures or noumena which are regarded as, by nature, transcendent, unalterable and historical." (p. 40) What we call feature clustering is identified by Windisch as follows: "This very common mechanism results in the creation of systems of objects, properties and values which can be defined as 'crystallised,' as each element in the system is linked to another by ideological association." (p 47)
} 
"[...] the Turkish-speaking separatist Gagauz minority [...]" (Guardian Weekly, 11 Nov. 1990, p. 6)

"[...] the Turkish-speaking Gagauz [...]" (The Guardian, 1 Nov. 1990, p. 4; The Guardian, 12 Nov. 1990, p.4)

"[...] de Gagaoezen, een Turkstalige minderheid [...] (NRC Handelsblad, 2 Nov. 1990, p. 5) $[<\ldots>$ the Gagauz, a Turkish-speaking minority <...>]

The feature clustering underlying group identification is such a powerful cognitive mechanism that knowledge about one feature is assumed to be enough, especially when it concerns language. As a result, groups that are distinguished solely on the basis of a distinct language are often treated as 'real' ethnic groups. And as such, they can be presented as being involved in inter-ethnic conflicts, even if their unity along the other parameters of the expected feature cluster does not stand up to scrutiny:

"Les violences entre Moldaves et russophones <...>." (Le Monde, 6 Nov. 1990, p. 8) [The violence between Moldavians and Russian-speakers <...>]

In this report, 'Russian-speakers' (referred to alternatingly as minorite russe or minorite russophone) are placed on a par with the Moldavians and the Gagauz. Here we see the dynamics of feature clustering at work. Though 'Russians' (the leastpreferred denominator in this report) could be reasonably assumed to share some common aspects of ethnicity, 'Russian-speakers' can obviously be no more than a residual category, an extremely heterogeneous group of people who may come from all over the Soviet Union, united only by the fact that they speak Russian (though it is certain that not all of them speak it as their mother tongue, and though even this feature does not clearly distinguish them from the other groups, as will be shown below), and by the fact that they cannot be labeled as ethnic Moldavians or Gagauz. But nevertheless the 'Russian-speakers' are presented, in direct opposition with Moldavians and Gagauz, as an equally solid ethnic unit.

This misrepresentation of the social formations involved in the conflict clearly hampers a fair understanding of what goes on in Moldavia: by applying familiar categories, the impression of clear understanding is created while in fact neither the authors nor the readers of the articles have any familiarity with the people talked about. This is further illustrated by another characteristic of our data: after language has been introduced as a categorizing criterion, distinctive features other than language may be dragged in as soon as they are known, irrespective of whether in reality they play an identifying or distinguishing role or not. This leads to strange descriptions such as the following.

"[...] de Gagaoezen -- een aan de Turken verwante christelijke minderheid - [...]." (NRC Handelsblad. 5 Nov. 1990, p 4.) [<...> the Gagauz -- a Christian minority related to the Turks $\ldots .<\ldots\rangle$.]

Thus our data show the emergence of religion as a further identifying feature of the 
Gagauz a few days after the first reports, though christianity in itself is precisely not a minority trait in Moldavia.

It may even be more surprising that this language-based identification is maintained though the distinguishing trait is almost in the same breath denied or downplayed.

"They [the Moldavians] claim the Gagauz are strongly Russianised; most speak Russian rather than Turkish and support Russian interests." (The Guardian, 1 Nov. 1990, p. 4)

Though this again casts doubt on the legitimacy of a movement (centered around people who have betrayed themselves by adopting another language), we'll come back to this example below to demonstrate further aspects of the linguistic framing of nationalism.

Before going on, let us briefly point out that the clustering of language, descent, history, culture and religion, the strength of which we have been trying to demonstrate, is even extended to economic position. Remember the following quote:

"Die ethnisch-rassische Koexistenz scheint zu gelingen solange die Wirtschaft einigermassen floriert." (Die Zeit, 9 Nov. 1990, p.7) [Ethnic-racial coexistence seems to work as long as the economy is somewhat successful.]

The relationship between (multi-)ethnicity and economic prosperity is a topic which deserves more than the few lines we can spend here. In general, there seems to be an intuitive, almost automatic, association between the rise of nationalism and economic problems. Thus a weak economy is a much favored excuse for manifestations of racism. But if economic factors can trigger interethnic conflicts, ethnic groups must be seen as socio-economically undifferentiated wholes which act and react en masse under economic pressure. ${ }^{7}$ The economy, which may soothe slumbering interethnic conflicts in times of general prosperity, is seen as flexible and unstable, whereas ethnicity is seen as a stable and timeless element of social stratification, a stratification which largely coincides with socio-economic differences.

\section{The different faces of homogeneism}

Since the discontinuities -- to pursue the lexical semantics metaphor further -- are

\footnotetext{
${ }^{7}$ The main exception to this rule seems to be the attempt, in official European rhetoric, to explain away racism and to preserve the European self-image of tolerance by demonstrating that expressions of racism are restricted to the lower socio-economic classes and that a weak socioeconomic status is itself the cause. (See Blommaert \& Verschueren 1991.) But this is just one manifestation of another rule: that it is easier to perceive significant distinctions in one's own group than in other groups. The phenomenon indicated here also explains the occurrence, in our restricted corpus, of a long article (Wider die falschen Apostel, Die Zeit, 9 Nov. 1990, pp. 54-56) in which an attempt is made to define 'normal nationalism,' and in which economic problems are presented as a risk factor which may transform normal nationalism into xenophobia.
} 
defined in terms of necessary and sufficient conditions which are so strongly. clustered that even one of them may be sufficient to characterize a group entity, homogeneity (emphasizing the necessity of the necessary and sufficient conditions) is the norm within the discontinuities (i.e. the 'nations' or 'peoples') thus defined. Since such a view is so obviously naive, adherence to it would be most passionately denied by the authors of most of the reports discussed when challenged about this. But here we touch upon a deeply engrained dogma which is very coherently -though mostly implicitly -- present in discourse about interethnic conflicts. Elsewhere (in Blommaert \& Verschueren 1991) we have called it the dogma of homogeneism: a view of society in which differences are seen as dangerous and centrifugal, and in which the 'best' society is suggested to be one without intergroup differences.

In other words, the ideal model of society is mono-lingual, mono-ethnic, mono-religious, mono-ideological. Nationalism, interpreted as the struggle to keep groups as 'pure' and homogeneous as possible, is considered to be a positive attitude within the dogma of homogeneism. Pluri-ethnic or pluri-lingual societies are seen as problem-prone, because they require forms of state organization that run counter to the 'natural' characteristics of groupings of people. This dogma appears to dominate Belgian (and European) immigrant policies (again, see Blommaert \& Verschueren 1991), and -- as will be further demonstrated below -- it is used as an interpretive frame (with the Soviet Union as evidence and example) even for situations outside of Europe in our corpus:

"Wie in die Sowjetunion stellt sich auch in Indien die frage, ob ein Riesenreich, das aus derartig vielen ethnischen, religiösen, sprachlichen und kulturellen Splittern zusammengesetzt ist, zusammengehalten werden kann." (Die Zeit, 16 Nov. 1990, p. 11) [As in the Soviet Union, the question also poses itself for India whether a giant empire consisting of such a plethora of ethnic, religious, linguistic and cultural fragments can be held together.]

The conceptual systematicity with which the norm of homogeneity turns language itself into an interethnic battlefield will be discussed in section 3. of this paper.

Though the norm of homogeneity is demonstrably present across Europe, the criteria along which homogeous nations are defined differ substantially. Let us briefly look at some of the different forms of expression the norm can take. We find it in its purest ethnic form in the German press, where das Volk is systematically contrasted with die Bevölkerung: the people vs. the population. For instance, the caption accompanying a picture with Turkish immigrants reads:

"Soll nur das Volk oder die Bevölkerung auf kommunaler Ebene politisch mitentscheiden dürfen? Türken auf einem SPD-fest in Berlin-Kreuzberg." (Die Zeit, 9 Nov. 1990, p.7) [Should only the people or the population participate in political decisions at the municipal level? Turks at a SPD-meeting in Berlin-Kreuzberg.]

Overtly, a clear position of tolerance is advocated:

"Deutschland wird, wie in der Geschichte schon oft, die Ausländer, die gekommen sind und bleiben wollen, 'integrieren." (Frankfurter Allgemeine, 
2 Nov. 1990, p.1) [Germany will, as often before in history, 'integrate' foreigners who have come and want to stay.]

Yet this claim is embedded in a plea for preserving voting rights at the municipal level for Staatsbürger (citizens)and against giving them to Bewohner or Einwohner (inhabitants). That the plea is not so much intended to protect all those who have acquired German citizenship, but mostly ethnic Germans, is made abundantly -- if unwittingly -- clear:

"Mithin ist es konsequent, dass in Deutschland namens des Begriffs der Demokratie [...] Versuche abgewehrt worden sind, die Begriffe Nation und Staat voneinander $\mathrm{zu}$ trennen und sie damit aufzulösen." (Frankfurter Allgemeine, 2 Nov. 1990, p.1) [Therefore it is logical that in Germany, in the name of democracy $<\ldots>$ attempts have been thwarted to tear the notions nation and state apart and hence to annihilate them.]

The author continues:

"Bisher is nichts Überzeugendes gesagt worden darüber, das die Verwischung des Begriffs der über die Staatsbürgerschaft verfügenden Angehörigen einer Nation, die in der Handlungseinheit Staat über sichselbst bestimmen, irgendwelche Vorteile habe. [...] Demokratie braucht fesst umrissene Einheiten." (Frankfurter Allgemeine, 2 Nov. 1990, p.1) [So far, nothing convincing has been said to show that it would have any advantages to eliminate the concept of a 'nation' with dependents possessing citizenship and determining their own fate within the action unit 'state.' Democracy needs clearly defined units.]

In the context of this article, the author does not leave any doubt that those fesst umrissene Einheiten are nation-states, the homogeneity of which should not be broken: to the extent that immigrants are tolerable as participants in social and political life, they have to be 'integrated.'

But it is exactly at this juncture that the paradox -- or the deadly logic -- of a nationalist ideology becomes clear. The definition of das Volk in terms of a feature cluster makes 'integration' impossible, as much as it requires that process. As soon as an Einwohner or member of the Bevölkerung has adapted to one parameter of Germanhood, any other feature may be arbitrarily focused on to preserve the difference. Thus language is only one feature in the cluster. Just as German Jews (even if indistinguishable in other respects) lacked the proper genetics, any migrant worker fluent in German and respecting all German laws and rules of public life, may still be stuck with the wrong descent, historical background, looks, religion: he or she cannot become a member of das Volk; his or her presence inevitably breaks the 'natural groupings' of people, the homogeneity of nations, the strictly separable units needed for democracy. Just consider the categories introduced in the following sentence:

"Nur gebürtige Deutsche und diejenigen, die ihnen kraft 'Volkszugehörigkeit' oder durch späteren Erwerb des Staatsangehörigkeit gleichgestellt sind, 
dürfen wahlen -- [...]." (Die Zeit, 9 Nov. 1990, p. 7) [Only those born as Germans and those who have been given the same rights on the basis of their 'membership in the people' or later naturalization, are allowed to vote $--<\ldots>$.]

Of the two categories who have to be given the rights which those born as Germans have 'naturally,' the first group (including the Aussiedler, descendants of earlier German emigrants) are immediately defined as belonging to das Volk. The second group will probably never make it: their children will be second-generation immigrants, not really gebürtige Deutsche.

In contrast to the German emphasis on an ethnic definition of das Volk (in terms of language, descent, culture, etc.), the French version of homogeneism stresses the importance of territoriality. The difference in emphasis has clear historical roots. The German quest for a nation-state was considerably facilitated by the spread of German dialects across a large part of Europe. Though only few people actively used a common language of culture, politically the geographical area in question had been so fragmented that language was not only a useful, but virtually the only possible, focus for unity. Moreover, by the time of German unification in the second half of the nineteenth century, European nationalism was taking a linguistic turn (expressed, i.a., in the insertion of a language question in national censuses). By contrast, when France needed to identify le peuple after the French revolution, the French language was no more than an administrative means for state-wide communication, a language which was shared (even in its dialectal variants) by less than $50 \%$ of the population. As a result, the search for selfidentification led to a reification of France itself as a natural and indivisible entity, the French 'people' consisting of everyone living in its territory. Though from the mid-nineteenth century onwards France has been 'successful' in imposing the French language and reducing the size of all its linguistic minorities, even today 'linguistic nationalism' is seen as a distinct type of nationalism with which the French do not ideologically associate themselves. Thus a sense of bemusement is hardly suppressed in an article on Les forcenés du nationalisme linguistique slovaque [The fanatics of Slovak linguistic nationalism]:

"Grévistes de la faim, ils campent devant le Conseil national slovaque depuis le vote, jeudi 25 octobre, d'une loi érigeant le slovaque en langue officielle de la Slovaquie." (Le Monde, 1 Nov. 1990, p. 7) [These hunger strikers have been camping outside the Slovak national Council since the vote, on Thursday October 25, which made Slovak the official language of Slovakia.]

Thus having introduced the event ambiguously, leaving open the interpretation that the plusieurs dizaines de jeunes (several dozens of young people) who are conducting a hunger strike, are protesting the new law passed by the forcenés (fanatics) of linguistic nationalism, the author then catches the reader by surprise:

"Pour eux, cette loi est trop laxiste: [...]." [For them, this law is too permissive:. $<\ldots>$.]

The hunger strikers are themselves the fanatics. They do not only want Slovak to 
be the official language, they want to take away any linguistic rights that the Hungarian, Gypsy, Polish, Ukrainian and German minorities within Slovakia might have.

In spite of this expression of astonishment concerning the lack of tolerance for linguistic discontinuity in the Slovak case, the territorially based French version of nationalism has as much trouble accepting discontinuities: within its borders, France is one. This is clearly expressed in the debate over Corsican separatism, and in particular the official acceptance of the very notion of a 'Corsican people.' That a debate over the fact that Le gouvernement reconnaît l'existence d'un "peuple corse" (Le Monde, 2. Nov. 1990, p. 1) [The government recognizes the existence of a 'Corsican people'] is at all necessary, and is treated as front-page news, is already significant. But the phrasing of that recognition is symptomatic of the French version of homogeneism:

"M. Mitterrand est intervenu pour que la notion de 'peuple corse' soit retenue en tant que 'composante du peuple français'." (Le Monde, 2 Nov. 1990, p. 1) [M. Mitterrand has defended the acceptance of the notion of a 'Corsican people' as a 'component of the French people'.]

In spite of this rhetorical attempt to avert discontinuity, questions are raised about the constitutionality of the government decision, and even about its logical possibility; and it is ridiculed as le modele polynesien (the Polynesian model), with reference to earlier decisions concerning French Polynesia. The French press avoids any reference to what the German press identifies an an underlying problem for those who are disturbed by the decision:

"Sie sehen voraus, dass wo ein Volk ist, auch ein Staat sein müsse, und sie befürchten, dass nach dem korsischen auch ein 'bretonisches,' ein 'baskisches' oder sogar ein 'elsässisches Volk' Ansprüche erheben könnte." (Frankfurter Allgemeine, 2 Nov. 1990, p. 6) [They anticipate that where there is a people, there must also be a state, and they fear that after the Corsicans also a 'Bretonic,' a 'Basque' or even an 'Alsatian people' could be making demands.]

Corsican nationalists are reportedly satisfied, while the most avid opposition comes from Le Pen's Front national:

"Le Front national "souligne les responsabilité [sic] que prendraient les parlementaires, les fonctionnaires ou, même, les citoyens qui attenteraient aux liens institutionnels qui placent la Corse dans la République et aux droits historiques et moraux de la patrie française en Corse."' (Le Monde, 3 Nov. 1990, p. 8) [The Front national "emphasizes the responsabilities that would be taken by those representatives, functionaries or even citizens who would make an attempt on the institutional ties which place Corsica within the Republic and on the historical and moral rights of the French fatherland in Corsica."]

Here again we find a fundamental paradox of nationalism: though grounded in the observation of 'existing' differences, once a separate entity has been defined, 
nationalism is unable to recognize the legitimacy of any smaller-scale (or larger) group identities. ${ }^{8}$

The data from the British press contain remarkably few references to ethnic or linguistic diversity within Britain. Still, one small article in The Guardian (entitled Welsh militants urge supporters to breed children 'for the cause') tells a lot. In this article, a meeting of Welsh nationalists is reported. One of their leaders is said to have pleaded for Welshmen to have as many children as possible, so as to perpetuate the Welsh language, in the following terms:

"If you cannot speak Welsh, you carry the mark of the Englishman with you every day. That is the unpleasant truth." (The Guardian, 12 Nov. 1990, p. 1)

Objectively, this is strong radical statement, revealing a degree of fanaticism mostly associated with radical nationalists. The meeting could, therefore, easily be taken seriously. But the opposite happens. The tone of the entire article is mildly ironical. The proposal to breed children in order to perpetuate the Welsh language is ridiculed. Moreover, the article ends with the suggestion that this proposal is reminiscent of the German Nazi 'Mutterkreuz' -- a suggestion which is strongly rejected by the speaker. But even this comparison, grave as it may sound on the surface, is basically ironic. Nationalism (or even more generally, ethnic diversity), at least within the UK, is treated as folklore: it is not to be taken seriously as a political movement in Britain. Welsh activists are sketched as picturesque, romantic people, who cherish old customs and values in a harmless way -- harmless because of the strength of the centralized, English-speaking state.

In Belgium, homogeneism is most manifest in the domain of immigrant politics. That the Flemish and the Walloons run their own business, quite separately, is taken for granted (to the point where even arms sales can become a regional matter). Real problems of diversity (and the resulting destabilization) are caused only by the presence of immigrants from Maghrebine or Mediterranean descent. Although the presence of these foreign elements in Belgian society is officially declared to be a form of 'cultural enrichment' (invoking a suggestion of tolerance and openness from the Belgian side), a detailed analysis (see Blommaert \& Verschueren 1991) reveals that Belgian society wants to be 'enriched' only in domains such as exotic cuisine, exotic music and dance -- in sum, folklore. Socially, culturally, and linguistically, if not religiously, immigrants should 'integrate' or deethnicize themselves, to the point where, as one government party's policy document on immigrants states, "Migrants should become Flemish." An intriguing side-effect, but one which cannot be elaborated within the scope of this paper, is the observation that in the discourse about immigrants in Belgium, the age-old division between Flemish and Walloons seems to vanish. The formulation of an attitude towards immigrant minorities has caused the (re)construction of a common Belgian

\footnotetext{
${ }^{8}$ Uli Windisch (1990) reports that Swiss nationalism has the same profile as French nationalism, being based necessarily -. because of the diversity of the people living in the country -. on territoriality. Thus Swiss nationalists cannot understand Jura separatism because "The only sociological division they recognise is that based on national frontiers: '[within Switzerland] there aren't any frontiers, we're all Swiss'." (p. 57)
} 
identity, thus allowing two clearly defined (and supposedly homogeneous) groups to form the core structure of a Belgian immigrant policy: 'Belgians' as opposed to 'Immigrants.' Needless to say that neither is, or has ever been, a homogeneous group.

\section{Of nations and tribes}

Very little disagreement seems to exist with regard to the reality of 'nations' in Europe. As demonstrated above, the 'nation' is presented as a natural, objective and almost biological unit. People are divided on the basis of sex, age, and nation. In spite of the general tendency in our data to accept the existence -- in 'reality' -- of 'nations,' explicit statements on the subject are rare. Treating this reality as selfevident effectively hides the fact that it rarely stands up to scrutiny. A potentially classical example to disprove the existence of objective criteria of nationhood is a comparison between the Serbs and the Croats on the one hand, and the Flemish and the Dutch on the other. In the Serbian-Croat case, existing linguistic differences (underscored by a different orthography) have become highly symbolic for the discontinuity, whereas in the Flemish-Dutch case (where the linguistic differences are of almost exactly the same type and degree) language is the main symbol of cultural unity. On all other counts, the differences are completely analogous as well: e.g., history (Ottoman rule for Serbia vs. Spanish rule for Flanders, resulting in long periods of political separation from Croatia and Holland, respectively); religion (Orthodox vs. Catholic in the one case, Catholic vs. Protestant/Calvinist in the other). In spite of its obviousness, not a single observation of this kind can be found in the corpus.

Interestingly, in the two explicit statements on the reality of nations which we have been able to find (one inside, and one outside the restricted corpus which is the starting point for the discussion in this article), a comparison is volunteered between nations or peoples in Europe and 'tribes.' Consider the following observation from a Belgian newspaper:

"Tijdens zijn jongste bezoek aan Duitsland heeft President Mitterrand met die Franse hooghartigheid die niet zelden wortelt in een gebrekkige dossierkennis, minachtend gewaarschuwd voor een 'Europe des tribus'. Maar of dat het Franse staatshoofd nu bevalt of niet, het is een feit dat die 'volksstammen' bestààn, erkenning, zeggenschap en een eigen plaats eisen in het Europa dat naar vereniging streeft." (De Standaard, 27 Sept. 1991, p. 10) [During his recent visit to Germany, President Mitterrand, displaying that French sense of superiority which is not rarely based on being ill-informed, has warned with disdain against a 'Europe of tribes.' But whether the French Head of State likes it or not, it is a fact that these 'tribes' exist, that they demand recognition, political participation and a place of their own in the Europe which is trying to reach unity.]

The term 'tribes' has a clear connotation of primitivism and naturalness in this context. And while Mitterrand's use of the term may be seen as ironic, the reaction from the journalist supports the view on nationalism as based on a need for identities analogous to groupings which are supposed to have come about quite 
naturally and instinctively in the less developed regions of the world. The resurgence of nationalism is therefore normal:

"Overal in Europa zien miljoenen mensen de kans schoon om oude dromen van kultureel zelfbestuur, zelfbeschikking en staatkundige onafhankelijkheid waar te maken. De verdwijning van de loden mantel die de kommunistische regimes over landen en volkeren hadden gelegd, heeft politieke en kulturele krachten vrijgemaakt die de komende decennia de landkaart van het kontinent kunnen hertekenen.

[...] Lang vergeten haarden van onrust en gevaar blijken nooit helemaal gedoofd te zijn geweest." (De Standaard, 27 Sept. 1991, p. 10) [Everywhere in Europe millions of people see the opportunity to realize old dreams of cultural independence, self-determination and state autonomy. The disappearance of the cloak of lead spread out over countries and peoples by the communist regimes, has released cultural and political forces which can redraw the map of the continent in the coming decades.

$<\ldots>$ Long forgotten centers of unrest and danger seem never to have vanished.]

The author uses history as the ultimate argument for the reality of the nations of Europe. These nations (Lithuania, Ukraine, Moldavia, Croatia etc.) do not emerge as responses to concrete political or socio-economic situations -- they were always there, but they were suppressed by totalitarian state systems (see section 3 . below). Their reality is historical, and therefore objectively real.

The same comparison, though in the opposite direction, is made in the opinion columns of the NRC Handelsblad (7 Nov. 1990, p. 9). The author, a professor of anthropology, argues against the European view of African 'tribes' as homogeneous, traditionalistic groups with rigid group boundaries. An explicit comparison with European nations or 'peoples' is not at all central to this well-taken argument. In the text itself it is introduced only indirectly:

"In Europa, zo zeggen Afrikanen, spreekt men van volken; als men het over Afrika heeft gebruikt men het woord stammen. Daarmee is weer bevestigd hoe primitief Afrika is." (NRC Handelsblad, 7 Nov. 1990, p. 9) [In Europa, Africans say, peoples are talked about; but as soon as Africa is the subject, the word tribes is used. This serves to reconfirm how primitive Africa is.]

But, maybe as a result of editorial intervention, the comparison is presented as the main focus of attention in the title:

"Wat in Afrika stammen heet, wordt in Europa als 'volkeren' getypeerd." [What is called tribes in Africa, is characterized as 'peoples' in Europe.]

Furthermore, by stressing that the view of African tribes which he argues against, is a decidedly 'European' view, the author implicitly communicates that the properties he rejects for those African tribes are genuine properties of European 'peoples' or 'nations.' Moreover, that similar 'nations' exist in Africa is made abundantly clear by stressing the unity of Tutsi and Hutu in Rwanda, in terms of a familiar feature cluster: 


\begin{abstract}
"Zij leven door elkaar als leden van één samenleving, bezitten één en dezelfde cultuur en spreken één taal." [They live together in one society, possess one and the same culture and speak one language.]
\end{abstract}

Thus again the objective reality of 'nations' is emphasised. Nowhere does it come to mind that groups -- wherever they are to be found -- have a strongly subjective basis, that 'nations' such as Lithuania or the Ukraine are defined territorially more than ethnically, and that they are therefore almost without exception multi-ethnic in population structure.

\title{
Obvious universality
}

Such comparisons between Europe and the rest of the world emphasize the universal validity of a nationalist ideology. When criticism of patriotism or nationalism is voiced and reported on, there are clear markers of distance between the opinions described and a more general public opinion. E.g. in a review of Peter Glotz's "Der Irrweg des Nationalstaats" we read:

"[According to Glotz] Das Geschichtsbild müsse europäisiert und Mehrsprachigkeit zum Bildungsprinzip gemacht werden. Kess spricht er von einer 'Hollandisierung Deitschlands' --ein Nationalbewusstsein ohne jeden Bezug zu völkischen, rassischen oder Sprachlichen Elementen.

Schön war's. Das soll kein Spott sein. Es sind solche Argumente, die Glotz in seinem querköpfigen, anregenden, eigensinnigen Essay auch dazu bringen, für Bonn als Regierungssitz zu plädieren."(Die Zeit, Nov 9 1990, p. 16) [Our historical perspective should <according to Glotz> be Europeanized, and multilingualism should be made an educational principle. He speaks boldly of the 'Hollandization of Germany' -- a national consciousness without reference to people, race or linguistic elements.

Wouldn't that be nice! And this is not even meant ironically. It is this type of argument that also leads Glotz, in this stubborn and highly personal essay, to a plea for Bonn as capital.]

Implicit in this is a perception of Holland as a nation untrue to itself because of lack of attention to real national identity and language. Strangely enough, Belgians tend to share this perception with the Germans. Thus the Antwerp mayor Cools takes every possible opportunity to explain that Dutch would have been taken over by French by now if it had not been for the Flemish. And after a recent colloquium on "Dutch in the World", a prominent linguist writes the following in an opinion article in De Standaard:

"Voor zijn taalkultuur zal Vlaanderen zich nu en in de toekomst moeten blijven richten naar het noorden: 15 miljoen geeft meer gewicht dan 5 miljoen. Maar voor de taalpolitiek is het anders. Daar zal Vlaanderen de bescheiden voortrekkersrol [...] zonder meer naar zich toe moeten trekken. In Vlaanderen ziet men de noodzaak in van de [...] instandhouding en verbreiding [van het Nederlands], voor Nederland is dat nog altijd een dubieuze zaak." (De Standaard, 22 Oct. 1991, p. 7) [For its language culture, 
Flanders has to look to the north now and in the future: 15 million carries more weight than 5 million. But for language policies the situation is different. There Flanders will simply have to assume its modest pioneering role. In Flanders one sees the need for the preservation and spread <of Dutch >, for Holland this is still a dubious matter.]

Needless to say that the perception reflected in the above German and Belgian texts bears only on Dutch official rhetoric. Our data show that 'the view from below' is not so different after all, and that the Germans and the Belgians can rest assured that nothing emanating from Holland will disturb their universally valid principles of social and political organization. Unfortunately, this cannot be meant ironically either.

\section{Language in the Empire}

\section{Language as a battlefield}

Our data indicate that language creates identity and discontinuity. It unites and it divides. In the context of conflicts involving nationalist groups in Europe (and elsewhere), these opposite tendencies turn language into the target and the battlefield of interethnic strife. Since language is a distinctive feature of 'natural' groups, and since it is an element of divisiveness between such groups, language can also be used as an object of oppression and discrimination in contexts where interethnic differences are not (or no longer) tolerated.

Dominant in the framing of this role of language is the metaphor of the 'Empire' in connection with tensions between a central government and 'national,' linguistic groups. The 'Empire,' in our corpus, mostly refers to the Soviet Union or to state systems based on the Soviet model. In all the examples found in our data, the tensions between the 'Empire' and national or ethnic groups are presented as resulting from the systematic denial by the empire of legitimate linguistic, cultural, and political rights. These minority groups claim the right to use their own language (or orthography), or to restore or introduce its official status as 'national language.' Since language is seen as a natural characteristic of these groups, such rights are held sacred even if the claims are uncompromising and radical in nature.

Linguistic discrimination by the Soviet Government is evoked as an example in statements such as:

"Their [the Kazakhs'] culture has been so defiled by the Bolshevikhs that many Kazakhs do not even know how to speak any other language than Russian" (Guardian Weekly, 11 Nov. 1990, p. 18)

"[...] a native Russian, Gennadi Kolbin, a party apparatchik who spoke not a word of the Kazakh language and had never been to the republic [of Kazakhstan]" (Guardian Weekly, 11 Nov. 1990, p. 18)

Soviet oppression is said to have resulted not only in the loss of local language competence among oppressed peoples in peripheral republics. It also resulted in 
changes in language attitudes and political partisanship:

"The done thing, in the Soviet Ukraine, was to speak Russian if you became educated." (Guardian Weekly, 4 Nov. 1990, p. 9)

"They claim that the Gagauz are strongly Russianized; most speak Russian rather than Turkish and support Russian interests." (The Guardian, 1 Nov. 1990, p. 4)

The same pattern occurs in Soviet sattelites, or in regimes that have adopted the Soviet model. Serbia's centralist attitude towards the Albanian population of the Kosovo region is such a case:

"The Albanian-language press and radio have been abolished". (International Herald Tribune, 12 Nov. 1990, p. 4)

When anti-Soviet nationalist groups, once they have gained autonomy or independence, stretch their nationalist fervor to the point of oppressing other minorities within their (supposedly) national territories, this is explained as a direct consequence of the repression and discrimination they have suffered:

"Moldawiens Hysterie [...] ist eine Folge des jahrzehntelangen Moskauer Diktats, das der rumänische Sprache sogar ein Kyrillisches Alphabet aufzwang." (Die Zeit 9 Nov. 1990, p. 1) [The Moldavian hysteria is a consequence of the decennia-long Moscow regulation, which even imposed a Cyrillic alphabet on the Rumanian language.]

In other words, the radicalism of newly autonomous or independent nationalist governments is not a product of their own ideology, but rather an understandable, yet potentially dangerous, reaction to generations-long oppression by the totalitarian imperial authorities. These hyper-nationalist reactions, however, threaten the possibilities of future collaboration among newly autonomous regions:

"Les violences entre Moldaves et russophones revêtent un aspect potentiellement explosif pour l'ensemble du pays." (Le Monde 6 Nov. 1990, p. 8) [The violence between Moldavians and Russian-speakers hides a potentially explosive situation for the country as a whole.]

The new forms of oppression often take the shape of legislation in favor of the majority language, banning other languages:

"In return, the republic's [= Moldavia's] government would soften a law that made Moldavian the national language and required people in dozens of occupations to pass tests in Moldavian. The language law has stirred resentment among Russian speakers and the Gagauz." (International Herald Tribune, 5 Nov. 1990, p. 5) 
"Pour eux [the Slovak hunger strikers protesting against a new language law], cette loi est trop laxiste: elle autorise l'usage des langues minoritaires dans les bureaux et services dans les regions ou les diverses minorites de Slovaquie comptent plus de $20 \%$ de la population locale." (Le Monde, 1 Nov. 1990, p. 7) [For them, this law is too permissive: it allows the use of minority languages in offices and services in regions where the various minorities in Slovakia make up more than $20 \%$ of the local population]

These new forms of oppression are supported by standard nationalist arguments associating national territory with national language. These arguments are, in our data, always presented as direct quotations:

"Lorsque je rentre dans un magasin dans le Sud [de la Slovaquie], on m'aborde en hongrois. Pourtant, je suis sur ma terre natale." (Le Monde, 1 Nov. 1990, p. 7) [When I enter a shop in the South <of Slovakia >, they address me in Hungarian. Yet, I'm on my native land]

"Maar waarom zijn er op de Israelische televisie wel programma's in het Arabisch en niet in het Russisch? We zijn nu toch in ons eigen land?" (NRC Handelsblad, 7 Nov. 1990, p. 4) [But why are there programs in Arabic on Israeli television and none in Russian? We are in our own country after all? < said by Russian Jewish immigrants in Israel >]

Though the ultimate absurdity of this cycle of oppression is not hidden by the reports, the underlying assumption of the legitimacy of each group's preoccupations is never challenged.

\section{Natural resistance and democracy}

At an abstract level, these examples invoke the image of an empire, consisting of a wide variety of linguistic, ethnic, religious, and cultural groups, most of which are oppressed by the unitarianism of the central state. Because the empire is oppressive, and because its oppression is directed against features which are absolute, inalienable characteristics of natural groups, the resistance of these groups is seen as necessarily legitimate. The struggle can only be conceptualized in terms of liberation or 'freedom' movements.

It is only natural that people revolt when they are deprived of their own language and culture. Consequently, the natural, normal and desired society is one in which these forms of oppression are absent: the nation-state in which people sharing one language, culture, religion and history live together within a sovereign state system. Here again, we find homogeneism as the underlying premisse.

The argument in favor of homogeneism remains complex and often obscure. In relation to Eastern Europe, it is blended with the discourse of anti-communism. The 'natural resistance' movements are directed against (the remnants of) communist rule. By a remarkable and largely implicit rhetorical twist, which defines communism as against human nature, East-European nationalism thus becomes an equivalent of democratization. The linguistic and cultural liberation of the EastEuropean peoples is at the core of the political liberation of the communist world, 
because nationalist revolt in the communist empire is aimed at liberating the 'natural' human group from unnatural communist rule. ${ }^{9}$

In other contexts (such as the 'giant empire' India, or minority problems in Belgium), the argument is stripped of its anticommunist connotations, and reduced to its supposed 'naturalness' or 'normality.' The backbone of the argument is thus the sole assumption that different people do not like to live together, and that successful society-building requires as high a degree of similarity as possible among the people.

The conceptual problems involved should be clear. First, homogeneism as a view of society rules out a number of social considerations. Class difference, socioeconomic status, or social mobility do not come up as factors of social coherence or conflict, except as properties of complete groups which correspond to the 'natural' criteria for identifying and separating them in the building of a peaceful, harmonious society. This is, to say the least, a partial picture obscured by - admittedly persuasive but necessarily mistaken -- monocausalism. Second, the direct association of (homogeneistic) nationalism with democracy and freedom is certainly not warranted by the facts, neither synchronically nor historically. Nationalism has been a notorious cause of conflicts, and has led to some of the worst events in history. Also, the 'liberated' Moldavians and Kazakhs or Slovaks, as well as the liberated East-Germans, seem to be building a track record of oppression and racism against minorities. Every minority has its own minorities. And for members of minority groups, be they immigrants in Western Europe, or Gagauz people in Moldavia, the 'national' government may be as bad as the empire, because in both cases very little attention is given to their linguistic, cultural or whatever rights. Only the structural level of the debate has shifted. Nothing has been achieved to guarantee more democracy in a pluralist sense.

\section{Multilingualism and tolerance}

Still, nationalism is seen as a 'natural' development anchored in linguistic and ethnic identities, a powerful liberation movement, the excesses of which are based on anger and frustration. Our data suggest an intriguing side-aspect of the role of language in this process. In three articles, two about the Israeli-Palestinian conflict in Israel and one on Serbian nationalism, reference is made to individual multilingualism as the opposite of fanaticism. The intriguing point is that this reference is made in a negative sense: even tolerant individuals who speak several languages fluently become fanatics. The orthodox bishop of Serbia, Amphilochios, a Serbian extremist, is said to speak fluent German (Frankfurter Allgemeine 6 Nov. 1990, p. 16). So here is an educated polyglot who serves a cause which is mostly associated with lower-

\footnotetext{
${ }^{9}$ Some recent scholarship about the Soviet Union shares the same assumptions. Thus Diuk \& Karatnycky (1990) say:"Yet all these current tensions [in the Soviet Union] arise from a common source--the imperial nature of the Soviet Union." (p. 16) Their book is a perfect example of unshakable belief in the fundamental reality of the Soviet Union's separable and authentic 'hidden nations.' Their holy rights to self-determination are strongly advocated and "the idea that the nonRussian national movements are anti-democratic and zenophobic" (p. 39) is discarded as a new Western myth-in-the-making. How could they be?
} 
class, poorly educated monomaniac masses. The same point is made with reference to some well-educated Palestinian highschool students, and a Jewish businessman who has worked with Arab personnel for years. The schoolboys have participated in the violent demonstrations following the Temple Mountain shootings; the Jewish shopkeeper does not trust his Arab employees anymore.

"Although such vows are extreme, these boys do not look or sound like 'Muslim fanatics'. <...> Schooled in an elite institution operated by the Christian Brothers, they are polite and well spoken, able to express themselves in English, French and Arabic." (International Herald Tribune, 6 Nov. 1990, p. 7)

\begin{abstract}
"Mr. Samar was born in Tel Aviv to parents who came from Iraq and he speaks fluent Arabic. In the last election he voted for a centrist party." (International Herald Tribune, 2 Nov. 1990, p. 5).
\end{abstract}

The picture that emerges here is the following. The struggle for legitimate national rights is such a central human interest that it eclipses even 'intelligent' and practical solutions, such as learning the language of one's counterpart. That means that a conflict between people based upon nationalist feelings is a fundamental conflict, one which cannot be remedied by slight forms of accommodation between the parties involved. In these references to the failure of individual multilingualism as a solution to interethnic conflicts resides a powerful suggestion about the nature of nationalism. It appears as both an emotional irrational matter and as a respectable phenomenon. The shortcomings of language learning, or education at large, as potential solutions for interethnic conflicts demonstrate that nationalism is based on the fundamental, natural, need for a homogeneous society. Man's political instinct, so to speak, directs him towards homogeneism. Quid erat demonstrandum.

\title{
4. Conclusions
}

Our corpus displays a remarkable consistency with regard to these assumptions. Homogeneism seems to be a widespread ideological premise, underlying much of the opinions reflected in or guided by the European newspaper press. We find a primitive political theory underlying seemingly trivial statements and suggestions about the role of language in nationalism. This theory revolves around the impossibility of heterogeneous communities, and the naturalness of homogeneous communities, the Volk. This theory also rationalizes anticommunism, not in terms of an ideological critique, not even in terms of an economic critique, but in terms of the supposedly unnatural character of the communist system. Nationalism thus provides the ultimate evidence for the just cause of the Cold War. The Cold War did not concern political-economic details, it was about fundamental, natural rights such as the right to use one's mother tongue.

The way in which the role of language in nationalist ideology is presented is largely political. The role of language as an element in feature clusters, corresponding to 'natural', objective political units, which makes it a mobilizing force 
in interethnic conflicts, obliterates the primarily social dimension of language. Language may equally characterize all members of one ethnic group, within that ethnic group its resources may be unevenly distributed along social lines, as so much empirical sociolinguistic work has demonstrated. But the feature cluster of 'culture' or 'ethnicity' functions as a powerful frame of reference. Less romantic (and maybe less easily accessible) factors virtually disappear from the picture, or their relevance is gravely downplayed.

The way in which language is presented in the overall reporting on nationalist ideologies in Europe reveals a decidedly unsophisticated folk view. Although our analysis in this paper was based on a relatively small set of data, we believe to have demonstrated the usefulness of a systematic search for the 'view from below' by means of a pragmatic analysis of patterns of wording. If applied with methodological rigor to larger sets of data, we believe that this type of analysis can provide an empirical tool for the investigation of elusive phenomena such as ideologies, public opinion, and ideas.

If nothing else, this brief study may have revealed a significant discrepancy between an aspect of popular language ideology and the way in which language is used in multilingual societies. As demonstrated by Woolard (1989) in connection with bilingualism in Catalonia, language choice is highly symbolic and language shift is often motivated by the dynamics of social mobility. In popular ideology (not to be confused with public ideology) however, language tends to be a much more fundamental, even natural and inalienable, aspect of ethnicity or group identity in general.

\section{References}

Adams, Karen L. \& Daniel T. Brink (eds.) (1990) Perspectives on Official English: The campaign for English as the official language of the USA. Berlin: Mouton de Gruyter.

Anderson, Benedict (1983) Imagined communities: Reflections on the origin and spread of nationalism. London: Verso.

Barth, Fredrik (ed.) (1982) Ethnic groups and boundaries: The social organization of culture differences. Oslo: Universitetsforlaget.

Blommaert, Jan \& Jef Verschueren (1991) "The pragmatics of minority politics in Belgium." Language in Society 20(4): 503-531.

Diuk, Nadia \& Adrian Karatnycky (1990) The hidden nations: The people challenge the Soviet Union. New. York: William Morrow and Company.

Hobsbawm, E.J. (1990) Nations and nationalism since 1780: Programme, myth, reality. Cambridge: Cambridge University Press.

Windisch, Uli (1990) Speech and reasoning in everyday life. Cambridge: Cambridge University Press.

Woolard, Kathryn A. (1989) Double talk: Bilingualism and the politics of ethnicity in Catalonia.

Stanford: Stanford University Press. 